Yüzüncü Y1 Üniversitesi
Tarim Bilimleri Dergisi

Araştırma Makalesi (Research Article)

\title{
Erciş (Van) Yöresinde Üzüm (Vitis spp.) Yetiştirmeye Uygun Potansiyel Alanların Coğrafi Bilgi Sistemleri (CBS) Teknikleri Kullanılarak İklim, Toprak ve Topoğrafya Faktörlerine Göre Belirlenmesi ${ }^{* *}$
}

\author{
Deniz Uğur GÜZEL ${ }^{1}$, Adnan DOĞAN ${ }^{* 2}$ \\ ${ }^{1}$ Türkiye Cumhuriyeti Tarım ve Orman Bakanlığı, 65100, Van, Türkiye \\ ${ }^{2}$ Van Yüzüncü Yıl Üniversitesi, Ziraat Fakültesi, Bahçe Bitkileri Bölümü, 65080, Van, Türkiye \\ ${ }^{1}$ https://orcid.org/ 0000-0003-2606-3985 ${ }^{2}$ https://orcid.org/ 0000-0002-8623-0629 \\ "Sorumlu Yazar e-posta: adnandogan@hotmail.com
}

\section{Makale Bilgileri}

Geliş: 14.06 .2020

Kabul: 25.08.2020

Online Yayınlanma 31.12.2020

DOI: 10.29133 /yyutbd.752603

\section{Anahtar kelimeler}

Coğrafi Bilgi Sistemleri (CBS), Uygunluk haritası, Üzüm (Vitis spp).
Öz: Türkiye, dünyada en çok tüketilen meyve olan üzümün (Vitis spp.) anavatanıdır. Ülkemiz bağcılık için elverişli iklim koşullarına sahip bulunmaktadır. Bu çalı̧̧ma ile iklim, toprak ve topoğrafya faktörleri göz önünde bulundurularak Coğrafi Bilgi Sistemleri (CBS) teknikleri ile farklı olgunlaşma düzeylerine sahip üzüm çeşitlerinin (Vitis spp.) Erciş ilçesi ve köylerinde potansiyel yetiştirilebilir alanların belirlenmesi amaçlanmıştır. CBS konumsal verilerin alan kullanım planlamasına yönelik olarak üretilmesi, düzenlenmesi ve birden fazla katmanın analiz edilebilmesi olanağını sağlamaktadır. Yapılan araştırmada bağcılık açısından; etkili sıcaklık toplamı, don olmayan gün sayısı, en düşük kış sıcaklıkları, eğim, bakı, toprak derinliği, toprak drenajı ve arazi kullanım kabiliyeti parametreleri incelenmiştir. $\mathrm{Bu}$ parametreler önemlilik düzeyine göre puanlamalara tabi tutulmuş ve bir modelleme uygulaması kullanılarak analiz edilmiştir. Araştırmaya konu on üzüm çeşidi için her olgunlaşma düzeyine göre üzüm çeşitlerinin yetiştirilebileceği alanlar belirlenerek uygunluk haritaları oluşturulmuştur. Çalışılan parametreler doğrultusunda Erciş yöresinin erkenci ve orta mevsim üzüm çeşitlerinin yetiştiriciliği için uygun olduğu söylenebilir.

\section{Determination of Suitable Areas for Grapes (Vitis Spp.) In Erciş (Van) Province According to Climatic, Soil and Topographic Factors by Using Geographic Information System (GIS) Technics}

\section{Article Info}

Received: 14.06.2020 Accepted: 25.08.2020

Online Published 31.12.2020

DOI: 10.29133 /yyutbd.752603

\section{Keywords}

Geographic Information System,

Suitability maps,

Grape (Vitis spp.).
Abstract: Turkey is the native land of grape (Vitis spp.) which is the most consumed fruit in the World. The country has suitable climate conditions for viticulture. In this study, considering climatic, soil and topographic factors, it was aimed to determine potential cultivation areas of grapes (Vitis spp.) with different ripening levels in Erciş (Van) center and its all villages by the help of Geographic Information Systems (GIS) techniques. GIS provides the possibility to produce, edit the spatial data, and analyze multiple layers for planning the usage of fields. In the research effective accumulated temperature, non-frost days, minimum winter temperatures, slope, aspect, soil depth, soil drainage, and land use ability parameters of viticulture were examined. These parameters were scored according to the significance level and analyzed by using a modeling application. For the 10 grape varieties selected for this study, the areas where grape varieties can be grown were determined and vineyard suitability maps were prepared according to each ripening level. According to the parameters 
studied, it can be said that the Erciş region is suitable for the cultivation of early and mid-season grape varieties.

** Çalışma birinci yazarın yüksek lisans tezinden üretilmiştir.

\section{Giriş}

Bağcılık, dünyanın en uygun iklim kuşağında yer alan ülkemiz için vazgeçilmez tarım kollarından biridir. Bu nedenle asma yetiştiriciliği yüzyıllardan beri yapılmaktadır. Bağcılık bir bütün olarak ülkemiz ekonomisinde önemli bir yer tutmaktadır. Üzüm, dünyanın en değerli meyveleri arasında hem üretim hem de sağladığ 1 katma değer itibariyle ilk sıradadır. Diğer yandan, hem asmasının, salkımının ve yaprağının güzelliği, hem de meyvesinin, şırasının ve yaprağının etkili ve yaygın kullanım potansiyeli dikkate alınarak "meyvelerin kraliçesi" olarak da tanımlanmaktadır.

Dünyada bağcılık ekolojik olarak $34^{\circ}-49^{\circ}$ Kuzey ve Güney enlemleri arasında yapılabilmektedir ve bu alan içerisinde yer alan birçok ülkede tarih boyunca birinci derece önem taşıyan bir tarım kolu olmuştur. Bu durumun başlıca nedeni ekonomik olarak üzümün sofralık, şaraplık, kurutmalık, meyve suyu ve diğer mamul ürünler seklinde değerlendirme olanağına sahip bir ürün olmasındandır. Ayrıca arazi değerlendirilmesi, toprak muhafazası, istihdam ve beslenme açısından da bağcilık, dünyada vazgeçilmez bir tarımsal faaliyet olarak günümüzde de önemini devam ettirmektedir (Çelik, 2018).

Yerkürenin Bağcıllk için en elverişli iklim kuşağı üzerinde bulunan Türkiye, asmanın gen merkezi olmasının yanı sıra, son derece eski ve köklü bir bağcılık kültürüne sahiptir. Dünya'nın en kaliteli sofralık, kurutmalık, şıralık ve şaraplık üzüm çeşitlerinin yetiştirildiği ülkemizde bağcılık tarımsal yapı içinde önemli bir yer tutmakta ve ülkemiz ekonomisine önemli katkılar sağlamaktadır. Bu katkının daha yukarılara çekilmesi mümkün olduğu halde, bu geleneksel tarım kolu son yıllarda fazlasıyla hak ettiği ilgi ve destekten mahrum kalmıştır. Bağların hızla tahrip olarak elden çıkması, ülkemiz bağcıllğında gerek alan gerekse üretim yönünden istatistiklere tam olarak yansımayan ciddi bir gerilemeye neden olmuştur. Bunun sonucu olarak çok değerli bağ alanları ve üzüm çeşitleri kaybedilme tehlikesi ile yüz yüze kalınmaktadır.

Van Gölü Havzası, karasal iklimin hâkim olduğu Doğu Anadolu Bölgesinde yer almasına rağmen, bir mikroklima iklim yapısına sahiptir. Yörenin bu özelliği yüksek rakımına rağmen birçok meyve türünün yetişmesine imkân sağlamaktadır. Yörenin ekolojik koşullarına en iyi uyum sağlayan meyve türlerinden birisi de üzümdür. Geçmişte yöre halkının önemli gelir kaynaklarından biri olan bağcılık binlerce yıldır koruduğu önemini son yıllarda hızla kaybetmeye başlamıştır. Bu gerilemenin altında yatan en önemli sebeplerden biri verim ve kalite düşüklüğüne nedeniyle elde edilen gelirin düşük olmasındandır (Uyak ve Gazioğlu-Şensoy, 2009).

Yaşadığımız çağda, bilgi teknolojisi çok değişik alanlarda yoğun bir şekilde insanlığa hizmet etmekte, özellikle mekanlara bağlı, yer ve konuma dayalı bilgilerin yönetilmesinde Coğrafi Bilgi Sistemleri (CBS) birçok ekonomik, sosyal ve kültürel kaynakların yönetimi ve entegrasyonu gibi karmaşık analiz gerektiren uygulamalarda önemli rol oynamaktadır (Akbaş ve ark., 2008).

Geleneksel yöntemlerle elde edilen bilgiler ve üretilen haritalar, ihtiyacı karşılamada yetersiz kalmakta, bu durum uzun zaman ve yüksek bir maliyet gerektirmektedir. Oysaki tarım alanlarının sürdürülebilir şekilde planlanabilmesi için doğru, güvenilir ve güncel bilgiye ihtiyaç duyulmaktadır. CBS ile bilgisayar ortamında kolay bir şekilde verilere ulaşılabilmekte, ilgili kararlar daha sağlıklı, etkili ve hızlı alınabilmektedir. Ayrıca karar vericiler, çiftçiler ve araştırmacılar gibi farklı kullanıcılar için mevcut veriler bir araya getirilerek yapılan mekânsal analizler ve sorgulamalarla yeni bilgiler üretilebilmektedir (Alsancak-Sırlı ve ark., 2015).

Bir yörenin bağcillğa uygunluğu konusunda karar verilirken öncelikle dikkate alınması gereken iki faktör, gelişme (vejetasyon) döneminin uzunluğu ve Etkili Sıcaklık Toplamıdır. Birbiri ile yakından ilişkili olan bu iki faktör de o yerin enlem derecesine, rakıma, büyük su kütlelerine yakınlığına, meyilin baktığı yöne ve derecesine göre değişmektedir. Ekonomik bir bağcılık için gelişme döneminin 180 günün, EST’nin ise 900 gün-derece üzerinde olması gerekir (Winkler ve ark., 1974, Ahmedullah ve Himelrick, 1990, Çelik ve ark., 1998).

Metot olarak örnek aldığımız Kurtural ve ark. (2008), yapmış olduğu çalışmada; Güney Illinois'de bağ alanlarının seçimi için bir Mekânsal Karar Destek Sistemi (MKDS) geliştirmiştir. CBS'den yararlanılarak yapılan çalışmada bölgedeki bağcılık alanlarının çeşitli kriterlere dayalı olarak 
(yükseklik, eğim, toprak özellikleri vb.) uygunluk analizleri yapılmış ve haritalanmıştır. Tarım, üretimin birden çok faktörün etkisinde bulunması nedeniyle planlama ve programlama (Ürün Modelleme) yapılması çok zor bir sektördür. Bu ve benzeri çalışmalar sayesinde Tarımsal Destek ve Planlama daha verimli bir şekilde gerçekleştirilecektir.

Bir bölgede yetiştirilecek üzüm seçimde özellikle bölgeye iyi adapte olmuş veya adapte olabilecek ekonomik çeşitler üzerinde durulmalıdır. Öncelikle çeşidin, yöre iklimine uygun olması gerekmektedir. Üzümün lezzet ve gösterişliliğinin yalnız çeşit özelliğinden değil, iklimin ve toprak yap1 ve bileşenlerinin etkisinden de meydana geldiği bilinmektedir. İklim unsuru içerisinde sıcaklık, 1şık, yağış, nem ve don ile birlikte yer, yön, rakım, rüzgâr, orman ve bağ tesis alanının büyük su kütlelerine, dağ ve tepelere yakınlığg kaliteli ürün elde etme üzerinde etkilidir (Öztürk, 1996).

Topografik yapı, toprak ve iklim özellikleri göz önüne alınarak hangi alanda hangi bitkilerin yetiştirilmesinin uygun olacağının belirlenmesine yönelik çalışmalar büyük önem taşımaktadır. Agroekolojik zonların temelini oluşturan bu çalışmaların bitki çeşidi bazında yapılması gerekmektedir. Ülkemizde daha çok yerinde tespit veya istatistiksel metotlar çerçevesinde yürütülen alan belirleme çalışmalarında son yıllarda CBS ve Uzaktan Algılama yöntemlerinden yararlanılmaktadır. Önemli bitki türlerinin her türlü özellikleri, coğrafyadaki dağılımları ve bu dağılışın iklim, toprak, eğim, bakı (yöney) ve coğrafik konum gibi bağımsız değişkenlerle ilişkileri CBS ile daha iyi analiz edilip modellenebilmektedir (Yıldırım, 2002). Söz konusu tür ve çeşitlerin coğrafyadaki dağılımlarının zaman içindeki değişimleri de CBS teknikleri ile kolaylıkla izlenebilmekte ve tehdit altındaki türlerin dağılış alanlarındaki artış veya azalış somut bir biçimde ortaya konulabilmektedir (Alsancak, 2005).

Çalışmanın amacı Van ilinde bağcılığın en yoğun olduğu alanların Erciş ilçesinde yer alması nedeniyle çalışma alanı olarak bu ilçe seçilmiştir. Farklı olgunlaşma düzeylerine sahip on üzüm çeşidinin yetiştirilebileceği en uygun alanlar ortaya konularak Erciş ilçesinde bağ alanı varlığının daha sağlıklı ve verimli bir şekilde arttırılmasına olanak sağlanmaya çalışılmıştır. Çalışma alanımızda çeşitli toprak, sıcaklık ve topografik özelliklerden oluşan parametreler dikkate alınmış ve bağcılık açısından çalışılan lokasyonun uygunluğu değerlendirilmiştir. Çalışma Van Gölü Havzasında bir ilk olma özelliğini taşımaktadır. Çalışmamız ile maliyetli ve zahmetli bir iş olan bağ tesisinin en uygun lokasyonlarda kurulmasına yardımcı olma böylece de zaman ve maliyet israfının önüne geçilmesi hedeflenmiş̧ir. Çalışılan alanda bir bağcılık tesisi kurulumu sırasında ilk bakılacak çalışma ve harita konumunda olacağı öngörülmektedir. Ülkemizde çalıştı̆̆ımız doğrultuda bağcılık açısından modelleme çalışması yapılmamış olup bir ilk niteliğindedir.

\section{Materyal ve Yöntem}

\subsection{Materyal}

Araştırmamız, 2017-2018 yılları arasında Yüzüncü Yıl Üniversitesi Ziraat Fakültesi Bahçe Bitkileri Bölümü’nde yürütülmüştür. Bu çalışmada bölgemizde bağcıllğın geçmişten beri en yoğun olarak yapıldığı Erciş ilçesi esas alınmıştır (Şekil 1). Erciş İlçesi Van Gölü’nün kuzeyinde Ağrı ve Bitlis illerine komşu konumda bulunmaktadır.

\subsubsection{Veri kaynakları}

Van ili Erciş ilçesi için Meteoroloji Müdürlügünden 1960-2012 yılları arasında ölçülen aylık iklim değerleri ile Köyleri için Climatedata verileri kullanılmıştır (Anonim, 2019). İlçeye ait Sayısal Arazi Modeli (SAM), 10 m çözünürlüklü ASTER uydu görüntüsünden elde edilmiştir. 1/25.000 ölçekli Türkiye il sınırları, ilçe sınırları, nehirler ve il sınırları veri tabanı olarak kullanılmıştır. Toprak verileri Tarım ve Orman Müdürlügü verileri ile Devlet Su İşleri verilerinden derlenmiştir. 


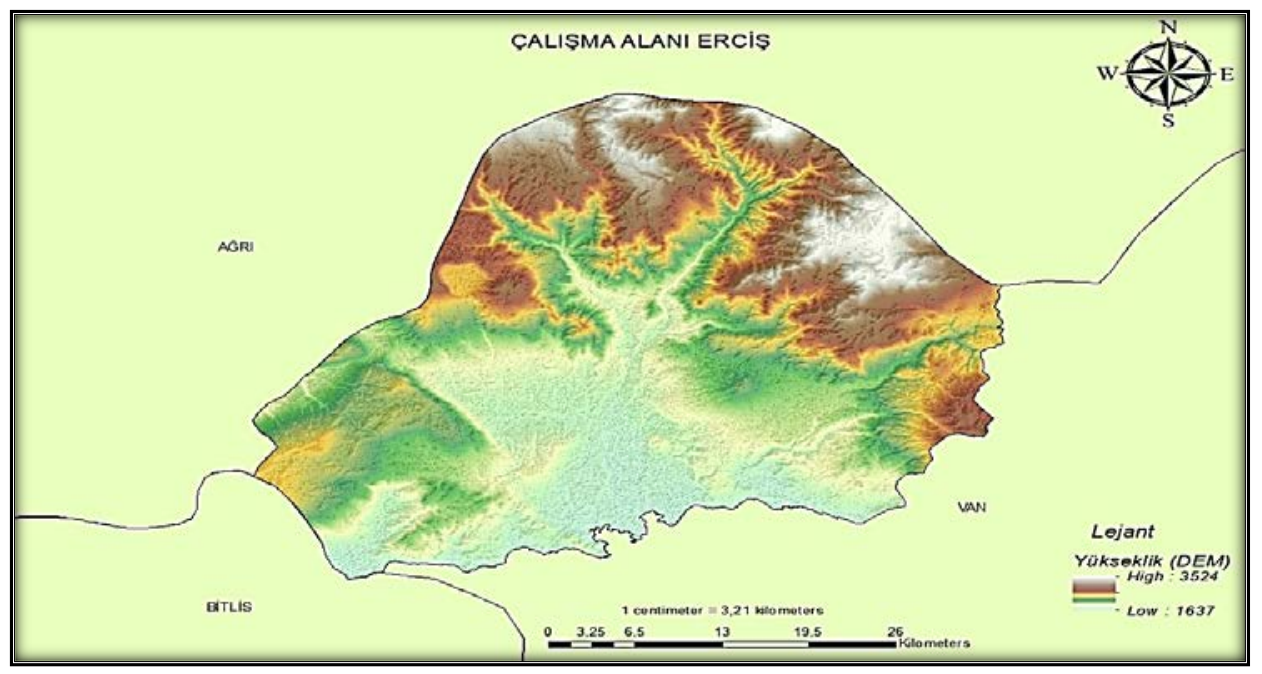

Şekil 1. Çalışma alanı.

Çizelge 1. Üzüm çeşitlerinin EST değerleri

\begin{tabular}{lcc}
\hline Üzüm Çeşitleri & Etkili Sıcaklık Toplamı İsteği & Olgunlaşma dönemi \\
\hline Trakya İlkeren & 1073 & Çok erkenci \\
Çavuş & 1233 & Erkenci \\
Yalova İncisi & 1360 & Orta Erkenci \\
Sultani Çekirdeksiz & 1380 & Orta Erkenci \\
Erciş Üzümü & 1395 & Orta Erkenci \\
Hamburg Misketi & 1408 & Orta Mevsim \\
Cardinal & 1440 & Orta Mevsim \\
Redglobe & 1437 & Orta Mevsim \\
Hatun Parmağı & 1440 & Orta Mevsim \\
Boğazkere & 1525 & Geçci \\
\hline
\end{tabular}

\subsubsection{Seçilen üzüm çeşitleri}

Gazioğlu-Şensoy ve Balta, (2010) tarafından yapılmış olan "Bazı Üzüm Çeşitlerinin Van Ekolojik Şartlarına Adaptasyonu" çalışmada Sultani Çekirdeksiz, Hamburg Misketi, Cardinal, Royal, Hatun Parmağı ve Yalova İncisi olmak üzere, altı sofralık üzüm çeşidinin, Van ekolojik koşullarına adaptasyon kabiliyetlerini üç yıl süreyle takip etmişlerdir. Çalı̧̧ma sonucunda Cardinal, Hamburg Misketi, Sultani Çekirdeksiz ve Yalova İncisi üzüm çeşitleri, bölgede yetiştiricilik için tavsiye edilmiştir. Tavsiye edilen çeşitler baz alınarak farklı olgunlaşma düzeylerine sahip Trakya İlkeren, Çavuş, Yalova İncisi, Sultani Çekirdeksiz, Hamburg Misketi, Cardinal, Redglobe, Hatun Parmağı, Boğazkere ve yöresel üzüm çeşidi olan Erciş Üzümü çeşitlerinin Erciş ilçesinde (ilçe merkezi ve köylerinde) yetiştiricilik düzeylerinin belirlenmesinde materyal olarak seçilmişlerdir. Belirlenen üzüm çeşitlerinin olgunlaşma dönemleri Çizelge 1'de verilmiştir (Çelik ve ark., 1998; Anonim, 2000; Çelik, 2002; Gazioğlu-Şensoy ve Balta, 2010).

\subsection{Yöntem}

Bu çalışmada Meteoroloji Genel Müdürlügü'nden ve Climatedata alınan 1960-2012 yılları arasında ölçülen iklim verileri Excel yazılımıyla düzenlenmiştir. Bu değerlendirmede her bir istasyona ait uzun yıllar iklim verilerinin aylık ve yıllık ortalamaları hesaplanmıştır (Anonim, 2018; Anonim, 2019). Bu ortalamalardan yararlanılarak iklim faktörlerinin dağılımını gösteren haritalar ArcGIS yazılımında hazırlanarak ilçenin merkez ve tüm köylerini kapsayan iklim haritaları oluşturulmuştur. Haritaların oluşturulmasında; uzun yıllar ortalama maksimum sıcaklık, uzun yıllar ortalama minimum 
sıcaklık, uzun yıllık ortalama sıcaklık, etkili sıcaklık toplamı, yıllık toplam yağış iklim parametreleri kullanılmıştır.

Ayrıca her bir çeşidin etkili sıcaklık toplamı isteği ve vejetasyon süreleri ayrı ayrı değerlendirilerek karşılaştırılmıştır. İklim elemanlarının alan üzerindeki dağılımının ortaya koyduğu haritalara göre ele alınan 10 üzüm çeşidinin değerlendirilmeye tabi tutulan parametreler açısından yetiştirilebilirlik düzeyleri belirlenmeye çalışılmıştır.

Herhangi bir yörenin bağcılık potansiyelini belirlemede yararlanılan en önemli parametre EST’dir (Etkili Sıcaklık Toplamı) (Çelik ve ark., 1998). Üzüm çeşitleri ürünlerini olgunlaştırabilmeleri için belirli bir sıcaklık toplamına gerek duyar. Gün-Derece (gd) olarak ifade edilen bu değerlerin hesaplanmasında genellikle asma için gelişmenin başladığı ortalama sıcaklık olarak kabul edilen $10^{\circ} \mathrm{C}$ (eşik sıcaklık) esas alınarak etkili sıcaklık toplamı hesaplanmış olup sonuçlar ArcGIS ortamına aktarılarak haritalanmıştır.

$$
E S T=\sum(T-T e)
$$

EST: Etkili sıcaklık toplamı $\left({ }^{\circ} \mathrm{C}\right.$-gün) T: Günlük ortalama sıcaklık $\left({ }^{\circ} \mathrm{C}\right)$ Te: Eşik sıcaklığ $\left({ }^{\circ} \mathrm{C}\right)$

Sayısal arazi modelinin oluşturulmasında ASTER uydusundan 2004 yılında çekilen görüntüden elde edilmiştir. Daha sonra sırasıyla sayısal arazi modelinden yararlanılarak ilin eğim haritası, bakı haritası, yükseklik haritası oluşturulmuştur. Koordinat sistemi olarak Universal Transverse Mercator (UTM) (European Datum 1950 UTM Zone 38N) kullanılmıştır.

Toprak verilerinin hazırlanmasında 1957 Köy Hizmetleri ile Tarım ve Orman Bakanlığının Statip projesi haritalarının derlenmesi sonucu oluşturulmuş veriler kullanılmıştır (Anonim, 2008). Toprak verileri içerisinde kullanılan özellikler; toprak drenaj durumu, toprak derinlik durumu, arazi kabiliyet sınıfları çalışmanın kapsamı içerisine dahil edilmiştir.

Coğrafi Bilgi Sistemi Uygulama programı olarak Esri adlı firmaya ait ArcGIS programının 10.2 versiyonu kullanılmıştır.

\subsubsection{Analizler}

Bağ uygunluk analizi sürecinin arkasındaki kavram karmaşık değildir. Virginia'da bağcılık potansiyeli için geliştirilen yöntem ve modelleri, (Boyer, 1998), Maryland Güney ve Doğu Kıyıları için bağ alanları seçimi (Fiola, 2007), Oregon Umpqua vadisi potansiyelinin analizi (Gregory ve ark., 2004), Pennsylvania bağ alanı değerlendirme sistemi (Day, 2006) ve diğer kaynakların yardımıyla Bağ yetiştiriciliğinde önemli bazı bireysel faktörlerin (EST, donsuz gün sayısı, minimum kış sıcaklığı, bakı, eğim, toprak drenajı gibi toprak özellikleri vb.) GIS analizi yardımıyla ve ağırlıklı oran sonuç yöntemi ile yöntemde formülize edilmek suretiyle uygunluk analizi yapılmıştır.

Çalışma alanı Erciş ilçesinin ASTER uydu görüntüsünden elde edilen Sayısal Arazi Modeli kullanılarak, ArcGIS-3D modülü ile bakı, yükseklik, eğim haritaları oluşturulmuştur. Bu şekilde ilçenin topoğrafya haritası ortaya konmuştur. İklim verileri işlenmek suretiyle donsuz gün sayısı, minimum kış sıcaklık puanı ile EST bulunmuş ve ArcGIS ortamına modelleme yapılabilmesi için haritalanmıştır. Toprak verileri de işlenerek ArcGIS programına uyumlu bir hale getirilmiş ve haritalanmıştır.

En sonunda ArcGIS Modelleme ile farklı katmanların bağ yetiştiriciliğine olan ilişki ve etkileri farklı oranlarda ortaya konulmak suretiyle uygunluk haritaları ortaya çıkarılmıştır. İklim ve toprak verileri ile çalışma alanlarından elde edilen sayısal veriler Microsoft Excel yazılımı ile CBS analizlerinde kullanılabilir hale getirilmiştir.

Erciş ilçesine ait verilerin işlenmesi ve alanların yükseklik, eğim, bakı özelliklerinin ortaya çıkarılmasında CBS tabanlı ArcGIS 10.2 ve temel modülleri kullanılmıştır.

Üzümde kaliteyi etkileyen iklim faktörlerini incelendiğinde; sıcaklık iklim elemanları içerisinde bağcılık için bakılması gereken ilk parametredir. Bir ekosistemde ekonomik anlamda bağcılık yapılabilmesi için; yıllık ortalama sıcaklığın $9{ }^{\circ} \mathrm{C}$ 'nin, en sıcak ay ortalamasının $18^{\circ} \mathrm{C}$ 'nin, en soğuk ay ortalamasının $0^{\circ} \mathrm{C}$ 'nin, yaz ayları ortalamasının 20 derecenin, gelişme dönemine (kuzey yarı küre için 1 Nisan-31 Ekim arası) ait ortalamanın ise 13 derecenin üzerinde olması gerekir. Diğer yandan y1llık ortalama sıcaklığı $11-16{ }^{\circ} \mathrm{C}$ arasında olan yörelerin bağcılık için en elverişli yöreler olduğu kabul 
edilmektedir (Çelik ve ark., 1998). Çalışma alanı olan bölge genel olarak Van Gölü’nün yumuşatıcı etkisi ile ılıman ve sıcak olduğu için üzüm çeşitlerinin sıcaklık ihtiyacını karşılamaktadır.

\subsubsection{Puanlama ve uygulanması}

Çalışmamız genel itibarı ile verilerin oranlanması ile oluşturulmuştur. Öncelikle veri çeşitleri ve ağırlıklarının hesaplanması için bağ yetiştiriciliğinde önemli bazı bireysel faktörlerin (EST, donsuz gün sayısı, minimum kış sıcaklığı, bak1, eğim, toprak drenajı gibi toprak özellikleri vb.) GIS analizi yardımıyla ve ağırlıklı oran sonuç yöntemi ile aşağıdaki gibi formülize edilmek suretiyle uygunluk analizi yapılmıştır.

$$
\sum_{i=1}^{n} A i x V i
$$

$\mathrm{Ai}=\mathrm{i}$ 'nci değişkeninin ağırlı̆̆

$\mathrm{Vi}=$ i'inci değişkenindeki sınıfının skoru

Yapılan çalışmanın analizinde (Etkili Sıcaklık Toplamı, don olmayan günler, minimum kış sıcaklığı, Bakı, Eğim, Toprak drenajı, Toprak derinliği, Arazi Kullanım Kabiliyeti) sekiz değişken bulunmaktadır. Araştırmada oluşturulan model şu şekilde ifade edilebilir:

Toplam Puan $($ Dizin değeri $)=$ Aest $\times$ Vest + Adog $\times$ Vdog + Amks $\times$ Vmks + Abak1 $\times$ Vbak1 + A ğgim $\times$ Veğim + Atdrnj $\times$ Vtdrnj + Atder $\times$ Vtder + Aakk $\times$ Vakk

Aest: Etkili sıcaklık toplamı ağırlı̆̆1

Adog: Don olmayan gün ağırlı̆̆ 1

Amks: Minimum kış sıcaklı̆̆ ağırlı̆̆ı

Aeğim: Ĕgim ağırlı̆̆g

Abakı: Bakının ağırlığı

Atdrnj: Toprak drenajının ağırlığı

Atder: Toprak derinlik ağırlığ 1

Aakk: Kullanım kabiliyeti ağırlığı
Vest: $\quad$ EST katmanındaki sınıfların değeri

Vdog: Donsuz gün sayısı katmanındaki sınıfların değeri

Vmks: Minimum kış sıcaklığı katmanındaki sınıfların değeri

Veğim: Eğim katmanındaki sınıfların değeri

Vbakı: Bakı katmanındaki sınıfların değeri

Vtdrnj: Toprak drenaj tabakasındaki sınıfların değeri

Vtder: Toprak Derinliği katmanındaki sınıfların değeri

Vakk: Arazi kullanım kabiliyeti katmanındaki sınıfların değeri

Yukarıda formülden görüldüğü üzere her bir değişkene (katman), bağ üzerinde tesir ettiği etkiye oranla belirli bir ağırlık (Ai) atanmıştır.

\subsubsection{Her bir katmanın ağırlık oranları}

Bağ yetiştiriciliğinde etkili her bir faktör 1'den 10'a kadar puanlanmış ve ağırlık oranları belirtilmiştir. Bu faktörlerin orantılanması sonucu yüzdelik etkileyicilikleri ortaya çıkmıştır. Skaladaki puanlamalar literatür taraması (Gregory ve ark., 2004; Fiola, 2005; Day, 2006; Kurtural ve ark., 2008) ve Van Yüzüncü Yıl Üniversitesi Bahçe Bitkileri Bölümü öğretim üyesi danışmanların katkısıyla belirlenmiştir (Çizelge 2-3).

Çizelge 2. Her bir katmanın ağırlık oranları

\begin{tabular}{lll}
\hline Değişkenler & Askala & Aorantı (\%) \\
\hline Etkili Sıcaklık Toplamı & 8 & 13.33 \\
Don Olmayan Gün Sayısı & 9 & 15.00 \\
En Düşük Kış Sıcaklığı & 10 & 16.67 \\
Bakı & 5 & 8.33 \\
Ĕ̆im & 6 & 10.00 \\
Toprak Derinliği & 8 & 13.33 \\
Arazi Kullanım Kabiliyet Sınıflaması & 7 & 11.67 \\
Drenaj Durumu & 7 & 11.67 \\
\hline Toplam & 60 & 100 \\
\hline
\end{tabular}




\section{FARKLI OLGUNLAŞMA DÜZEYLERİNE SAHİP \\ ÜZÜM ÇEŞITTLERININ UYGUNLUK ANALIZZ MODELLEMESI}

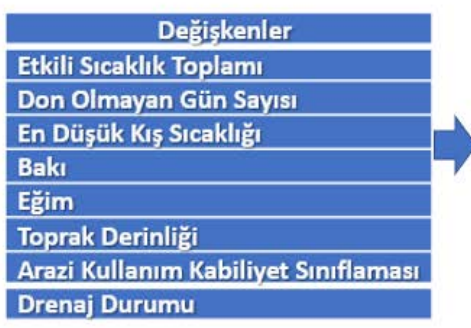

Sonuç

Katmanı

Etkili Sıcaklik Toplamı

Don Olmayan Gün Sayıs

En Düşük Kı ş Sıcaklı:̆

Reclassify

Yeni

Data

Weighted

Overlay

Reclassify

Arazi Kullanum Kabiliyet Sinuflamas

Uygunluk

Analiz

Sonucu

Şekil 2. Üzüm çeşitlerinin uygunluk analiz modellemesi.

Çizelge 3. Modellenecek olan katmanların kendi içerisindeki ağırlık oranları

\begin{tabular}{|c|c|c|c|c|c|}
\hline \multicolumn{6}{|c|}{ Etkili Sıcaklık Toplamı (EST) } \\
\hline Gün-Derece & $\begin{array}{c}\text { En } \\
\text { Erkenci }\end{array}$ & Erkenci & $\begin{array}{c}\text { Orta } \\
\text { Erkenci }\end{array}$ & $\begin{array}{c}\text { Orta } \\
\text { Mevsim }\end{array}$ & Geçci \\
\hline $800-900$ & 3 & 1 & 0 & 0 & 0 \\
\hline $900-1000$ & 6 & 3 & 1 & 0 & 0 \\
\hline $1000-1100$ & 10 & 5 & 3 & 1 & 0 \\
\hline $1100-1200$ & 10 & 7 & 5 & 3 & 1 \\
\hline $1200-1300$ & 10 & 10 & 7 & 5 & 3 \\
\hline $1300-1400$ & 10 & 10 & 10 & 7 & 5 \\
\hline $1400-1500$ & 10 & 10 & 10 & 10 & 7 \\
\hline $1500-1600$ & 10 & 10 & 10 & 10 & 10 \\
\hline $1600<$ & 10 & 10 & 10 & 10 & 10 \\
\hline \multicolumn{6}{|c|}{ Olgunlaşma Durumlarına Göre Don Olmayan Gün Puan Aralıkları } \\
\hline $\begin{array}{ll}\text { Günler } \quad \mathrm{E} \\
\end{array}$ & En Erkenci & Erkenci & Orta erkenci & Orta Mevsim & Geçci \\
\hline$<150$ & 1 & 0 & 0 & 0 & 0 \\
\hline $150-160$ & 3 & 1 & 0 & 0 & 0 \\
\hline $160-170$ & 5 & 3 & 1 & 0 & 0 \\
\hline 170-180 & 7 & 5 & 3 & 1 & 0 \\
\hline 180-190 & 10 & 7 & 5 & 3 & 1 \\
\hline 190-200 & 10 & 10 & 7 & 5 & 3 \\
\hline $200-210$ & 10 & 10 & 10 & 7 & 5 \\
\hline $210-220$ & 10 & 10 & 10 & 10 & 7 \\
\hline $220-230$ & 10 & 10 & 10 & 10 & 10 \\
\hline $230>$ & 10 & 10 & 10 & 10 & 10 \\
\hline
\end{tabular}

Eğim Durumu Puanları

\begin{tabular}{ll}
\hline Eğim & Puanlama \\
\hline Düz Alanlar & 3 \\
$\% 1-3$ & 5 \\
$\% 3-10$ & 10 \\
$\% 10-15$ & 7 \\
$>\% 15$ & 1 \\
\hline
\end{tabular}

Arazi Kullanım Kabiliyet Sınıfları

\begin{tabular}{|c|c|c|c|}
\hline & \\
\hline AKK Sinıfları & Puanlama & Toprak Derinliği & Puanlama \\
\hline I. Sinıf & 10 & $90+$ & 10 \\
\hline II. Sinif & 9 & $60-90$ & 7 \\
\hline III. Sinıf & 8 & $30-60$ & 4 \\
\hline IV. Sinıf & 7 & $30-$ & 1 \\
\hline V. Sinıf & 5 & & \\
\hline VI. Sinıf & 4 & & \\
\hline VII. Sinıf & 3 & & \\
\hline VIII. Sinif & 1 & & \\
\hline
\end{tabular}




\subsubsection{Băg uygunluk analizi-modelleme} sunulmuştur.

ArcGIS programında hazırlanan "Bağ Uygunluk Modellemesi” nin algoritması Şekil 2'de

\section{Bulgular}

Yapılan Analizlerde CBS kullanılan Haritalama programı ArcGIS'in “Weight Overlay” modülü kullanılarak tüm parametreler belirli ağırlıklarda katmanlar üst üste bindirilmiştir. Bu katmanların etki değerleri yöntemde belirtildiği oranlarda etki ederek Erciş ve tüm köyleri için iklim, toprak ve topografik sekiz kritere göre on üzüm çeşidi için uygunluk haritaları oluşturulmuştur. Çalışmada belirlenen uygunluk seviyeleri olan 1. uygunluk seviyesi mükemmel, ikinci uygunluk iyi, üçüncü uygunluk seviyesi kabul edilebilir seviyeler olarak belirlenmiştir. Üzüm çeşitlerinin olgunlaşma düzeylerine göre elde edilen sonuçlar Şekil 3-9’da sunulmuştur.

\section{1. Çok erkenci çeşitlerinin seviyelere göre alan dağılımları}

Çalışma alanımız olan Erciş İlçesinde, seçilen en erkenci üzüm çeşidi olan Trakya İlkeren için, yapılan analiz sonucu ortaya çıkan en uygun yetiştiricilik lokasyonları Şekil 3 ve Çizelge 4'de görülmektedir. Verilen harita incelendiğinde üç uygunluk seviyesinde Erciş ilçesinin büyük çoğunluğunun Trakya İlkeren çeşidinin değerlendirmeye konu faktörler açısından yetiştirilmesine uygun olduğu gözlemlenmektedir. En uygun alanlar ise Erciş ilçe merkezi ve güney kısmı ile ilçenin orta kısımlarından güney sınıra kadarki düzlük ve bağcılık yapılabilir nitelikteki eğimli alanlar olarak ortaya çıkmıştır.

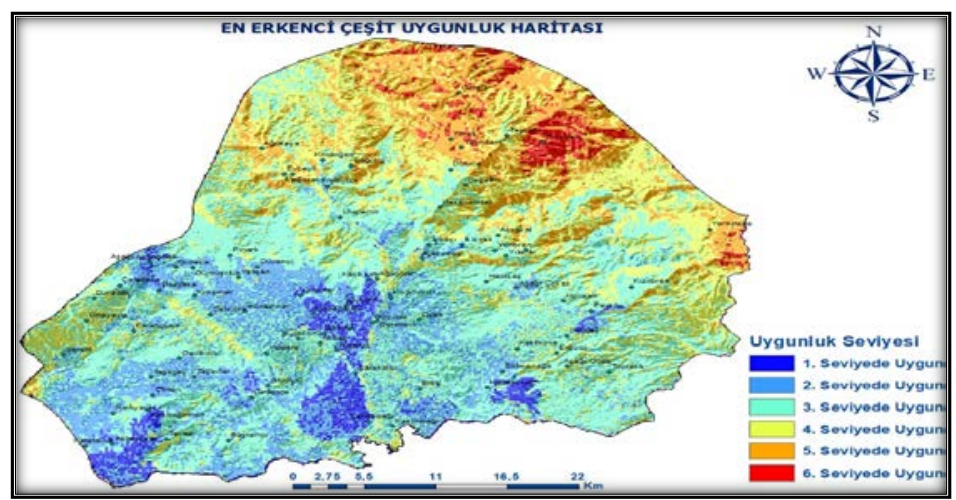

Çok erkenci birinci seviyede uygun olan köyler
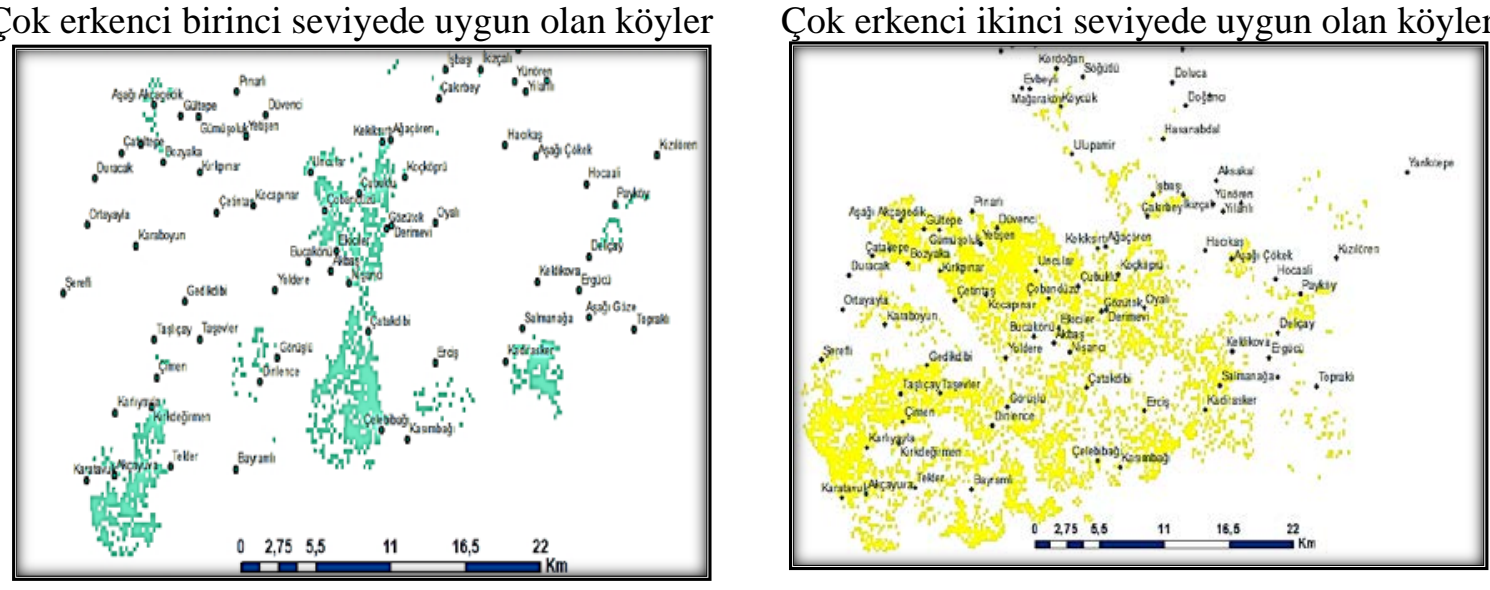

Şekil 3. Çok erkenci çeşitlerinin uygunluk seviyelere göre alan dağılımları. 
Çizelge 4. Çok erkenci Çeşit olan Trakya İlkeren Çeşidinin Yetiştirilebileceği Uygun Alan Dağılımları

\begin{tabular}{lcc}
\hline Uygunluk Sinfflamas1 & Alan (ha) & $\%$ \\
\hline 1. Seviyede Uygun & 3192 & 3.6 \\
2. Seviyede Uygun & 27010 & 15.3 \\
3. Seviyede Uygun & 71679 & 40.6 \\
4. Seviyede Uygun & 44161 & 25.0 \\
5. Seviyede Uygun & 22440 & 12.7 \\
6. Seviyede Uygun & 4934 & 2.8 \\
\hline
\end{tabular}

En erkenci çeşit için yapılan uygunluk analizinde görüleceği üzere Birinci seviyede uygun olan alanların dağılımı 3192 ha olup Birinci uygunluk seviyesinde bulunan köyler; Çatakdibi, Çelebibağ, Ekiciler, Gözütok, Kadirasker, Kırkdeğirmen, Akçayuva köylerinin belirli kısımları bu uygunluk seviyesine dâhil olmuştur.

İkinci uygunluk alanları içerisine dâhil olan köyler ise: Düvenci, Yetişen, Kocapınar, Çetintaş, Gültepe (az bir kısmı), Gedikdibi, Karlıyayla, Karatavuk, Bayramlı, Taşevler, Taşlıçay, Gözütok, Oyalı, Kırkpınar, Aşağıçökek ve Çakırbey köyler yer aldığı tespit edilmiştir olup alan dağılımları Şekil 2'de gözlemlenmektedir.

\subsection{Erkenci çeşitlerinin seviyelere göre alan dağılımları}

Erciş İlçesinde, erkenci üzüm çeşidi olarak değerlendirmeye tabi tutulan Çavuş üzümü için yapılan analiz sonucu ortaya çıkan birinci ve ikinci uygunluk seviyelerinde yetiştiricilik lokasyonları Şekil 4 ve Çizelge 5'de görülmektedir. En erkenci çeşit olan Trakya İlkeren ile karşılaştırıldığında ilk üç uygunluk seviyedeki alan miktarının azaldığı ve Erciş ilçesinin kuzey kısımlarındaki topografik olarak yüksek alanlarının 4., 5. ve 6. Seviyeye gerilediği görülmektedir. Çavuş üzüm çeşidinin yetiştirilebileceği alanların Van Gölü'ne yakınlıklarının 15-20 km uzaklıkta olduğu gözlemlenmektedir. Yine en uygun alan olan 1 ve 2 . Seviye uygunluklara ait lokasyonlarının benzerlik gösterdiği gözlemlenmektedir.

Çizelge 5. Erkenci Çeşit olan Çavuş Çeşidinin Yetiştirilebileceği Uygun Alan Dağılımları

\begin{tabular}{lcc}
\hline Uygunluk Sinıflamas1 & Alan (ha) & $\%$ \\
\hline 1. Seviyede Uygun & 5061 & 2.80 \\
2. Seviyede Uygun & 21832 & 12.30 \\
3. Seviyede Uygun & 60165 & 34.06 \\
4. Seviyede Uygun & 33213 & 18.80 \\
5. Seviyede Uygun & 35228 & 19.94 \\
6. Seviyede Uygun & 21107 & 11.95 \\
\hline
\end{tabular}

Birinci seviyede uygun olan alanların dağılımı 5061 ha'dır. İkinci seviyede uygun olan alanların dağılımı 21832 ha olup kapladığı alan \% 12.3 seviyesinde bulunmuştur. 


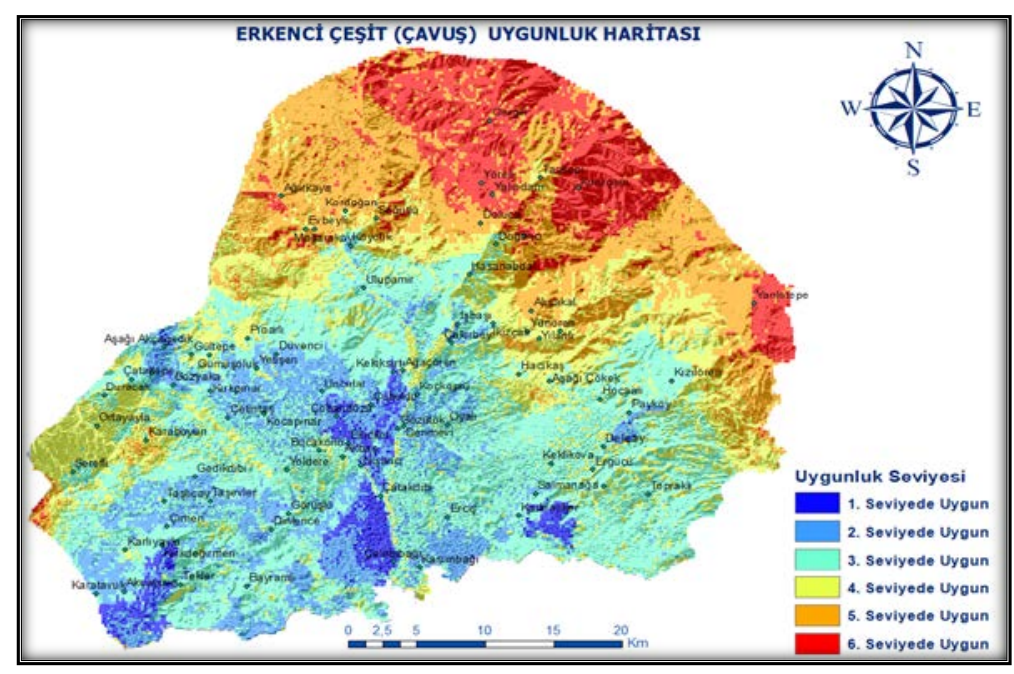

Erkenci birinci seviyede uygun olan köyler

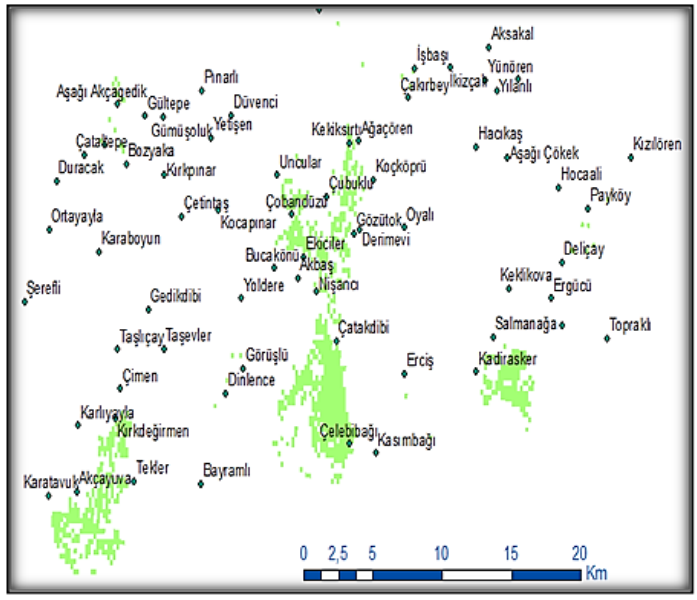

Erkenci ikinci seviyede uygun olan köyler

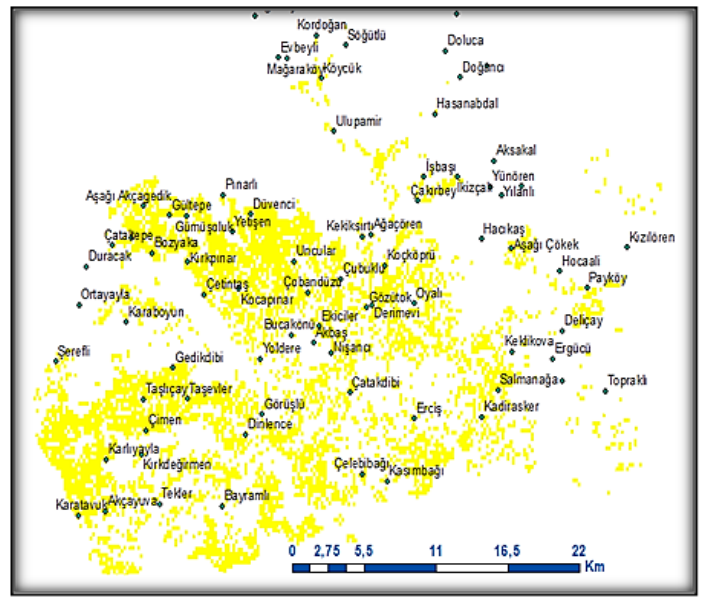

Şekil 4. Erkenci çeşitlerinin uygunluk seviyelere göre alan dağılımları.

\subsection{Orta erkenci çeşitlerinin seviyelere göre alan dağılımları}

Orta erkenci çeşitler olarak belirlenen Yalova İncisi ve Sultani Çekirdeksiz çeşitlerinin uygunluk haritasında Erciş ilçesinin kuzey kısımlarındaki uygun alanların çok azaldığı görülmektedir (Şekil 5). En uygun alanların yine Kadirasker, Çanaklı, Çelebibağı ve Tekler köyleri civarı olduğu belirlenmiştir.

Çizelge 6. Orta erkenci çeşitler olarak belirlenen Yalova İncisi ve Sultani Çekirdeksiz yetiştirilebileceği uygun alan dağılımları

\begin{tabular}{lcc}
\hline Uygunluk Sinıflamas1 & Alan (ha) & $\%$ \\
1. Seviyede Uygun & 3617 & 2.04 \\
2. Seviyede Uygun & 15110 & 8.50 \\
3. Seviyede Uygun & 42177 & 23.80 \\
4. Seviyede Uygun & 32721 & 18.50 \\
5. Seviyede Uygun & 30087 & 17.03 \\
6. Seviyede Uygun & 52893 & 29.90 \\
\hline
\end{tabular}

Birinci seviyede uygun olan alanların dağılımı 3617 ha olup kapladığı alan \% 2.04 seviyesinde bulunmuştur. İkinci seviyede uygun olan alanların dağılımı 15110 ha olup kapladığı alan \% 8.5 seviyesinde bulunmuştur (Çizelge 6). 


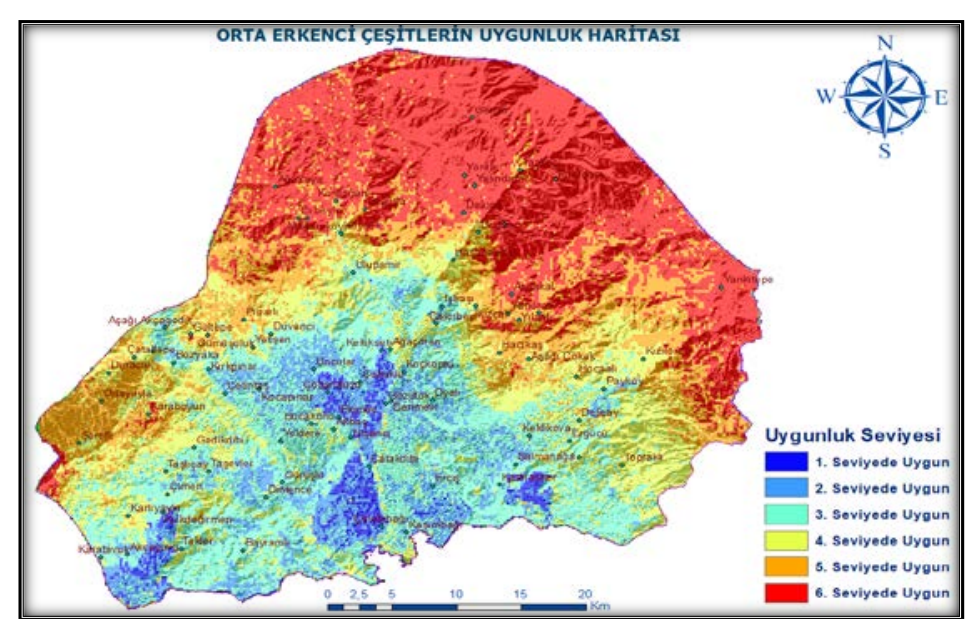

Orta erkenci birinci seviyede uygun olan köyler

Orta erkenci ikinci seviyede uygun olan köyler
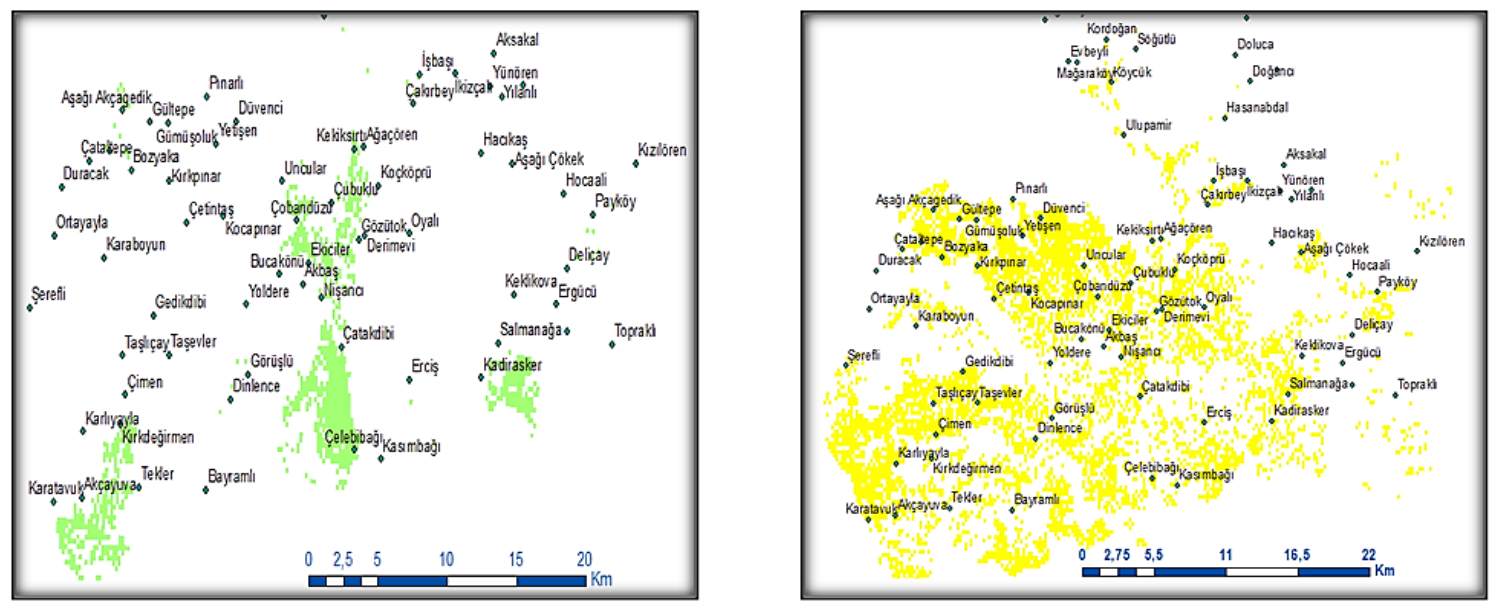

Şekil 5. Orta erkenci çeşitlerinin uygunluk seviyelere göre alan dağılımları.

\subsection{Orta mevsim çeşitlerin uygunluk analizi}

Orta Mevsim çeşitleri olarak değerlendirmeye alınan Hamburg Misketi, Cardinal, Redglobe, Hatun Parmağı çeşitlerin belirlediğimiz sekiz faktör açısından yapılan modelleme analizi sonucu çıan uygunluk haritası Şekil 6'da görülmektedir.

Çizelge 7. Orta mevsim olarak tanımlanan Hamburg Misketi, Cardinal, Redglobe, Hatun Parmağ1 çeşitlerin yetiştirilebileceği uygun alan dağılımları

\begin{tabular}{llr}
\hline Uygunluk Sinfflamas1 & Alan (ha) & $\%$ \\
\hline 1. Seviyede Uygun & 3363 & 1.90 \\
2. Seviyede Uygun & 13163 & 7.45 \\
3. Seviyede Uygun & 32266 & 18.27 \\
4. Seviyede Uygun & 27850 & 15.76 \\
5. Seviyede Uygun & 31970 & 18.10 \\
6. Seviyede Uygun & 67992 & 38.49 \\
\hline
\end{tabular}

Birinci seviyede uygun olan alanların dağılımı 3.363 ha olup kapladığı alan \% 1.9 seviyesinde bulunmuştur. İkinci seviyede uygun olan alanların dağılımı 13.163 ha olup kapladığı alan \% 7.45 seviyesinde bulunmuştur (Çizelge 7). 


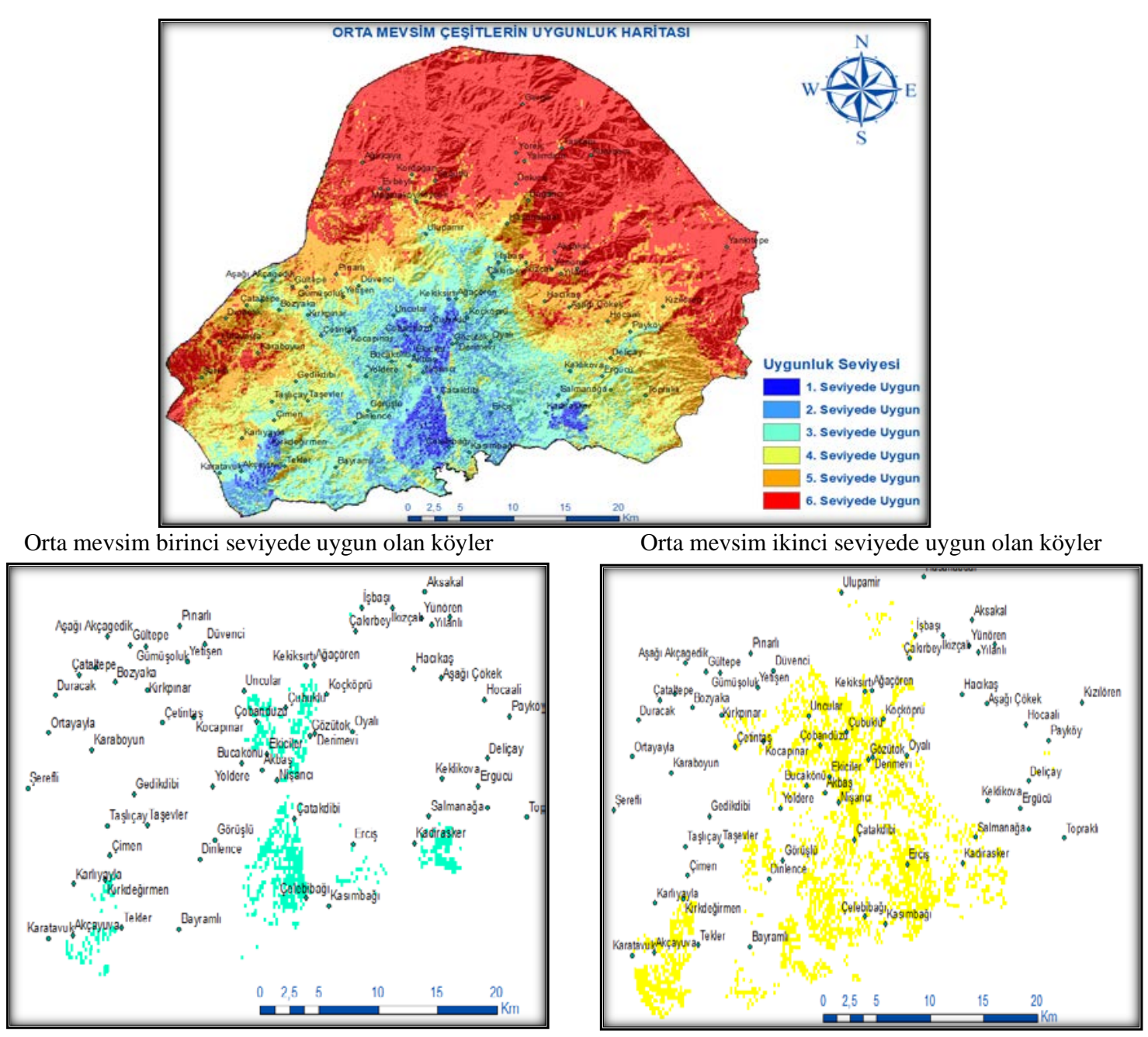

Şekil 6. Orta mevsim çeşitlerinin uygunluk seviyelere göre alan dağılımları.

Şekil 6'da görüldüğü üzere erkenci çeşitlere nazaran en uygun alanlar benzerlik göstermektedir. Hatta sahile yakın bazı alanların da yetiştiriciliğin tavsiye edilmediği alanlar olan Van Gölüne doğru yakınlaşmış olması bu çeşitlerin yetiştiriciliğinin dikkatli bir şekilde ve sınırlı yapılması gerektiği sonucunu ortaya koymaktadır. Şayet orta mevsim çeşitleri yetiştirilecek olsa birinci uygunluk seviye haritasında tespit edilen alanlar bazlı çok kısıtlı kesimlerde yapılabileceği saptanmıştır.

Orta Mevsim olarak adlandırdığımız Hamburg Misketi, Cardinal, Redglobe, Hatun Parmağı çeşitlerin belirlediğimiz sekiz faktör açısından yapılan modelleme analizi sonucu çıkan uygunluk haritasında gözleneceği üzere uygunluk alanlarının Van Gölüne doğru yakınlaşmış olması bu çeşitlerin yetiştiriciliğinin dikkatli bir şekilde ve sınırlı yapılması gerektiği sonucunu ortaya koymaktadır.

\subsection{Geçci çeşidin uygunluk analizi}

Şekil 7 ve Çizelge 8'de geçci Boğazkere çeşidinin seçilmiş sekiz sınırlayıcı faktöre göre uygunluk analizi haritası gözlemlenmektedir. Haritaya göre Erciş ilçesi geçci Boğazkere üzüm çeşidi için birinci ve ikinci seviyede uygun alanlar bulunmamaktadır. Ancak üçüncü seviyede çok kısıtlı alanlarda riskli bir yetiştiricilik yapılabilse de muhtemelen üzüm olgunlaşmasını tamamlayamadan vejetasyonun tamamlanacağ düşünülmektedir. Erciş ilçesi geçci çeşitlerin yetiştirilmesine uygun değildir. 
Çizelge 8. Orta mevsim olarak adlandırdığımız Hamburg Misketi, Cardinal, Redglobe, Hatun Parmağı çeşitlerin yetiştirilebileceği uygun alan dağılımları

\begin{tabular}{lrc}
\hline Uygunluk Sinıflamas1 & Alan (ha) & $\%$ \\
1. Seviyede Uygun & 0 & 0 \\
2. Seviyede Uygun & 0 & 0 \\
3. Seviyede Uygun & 724 & 0.41 \\
4. Seviyede Uygun & 7562 & 4.28 \\
5. Seviyede Uygun & 52464 & 29.70 \\
6. Seviyede Uygun & 115855 & 65.60 \\
\hline
\end{tabular}

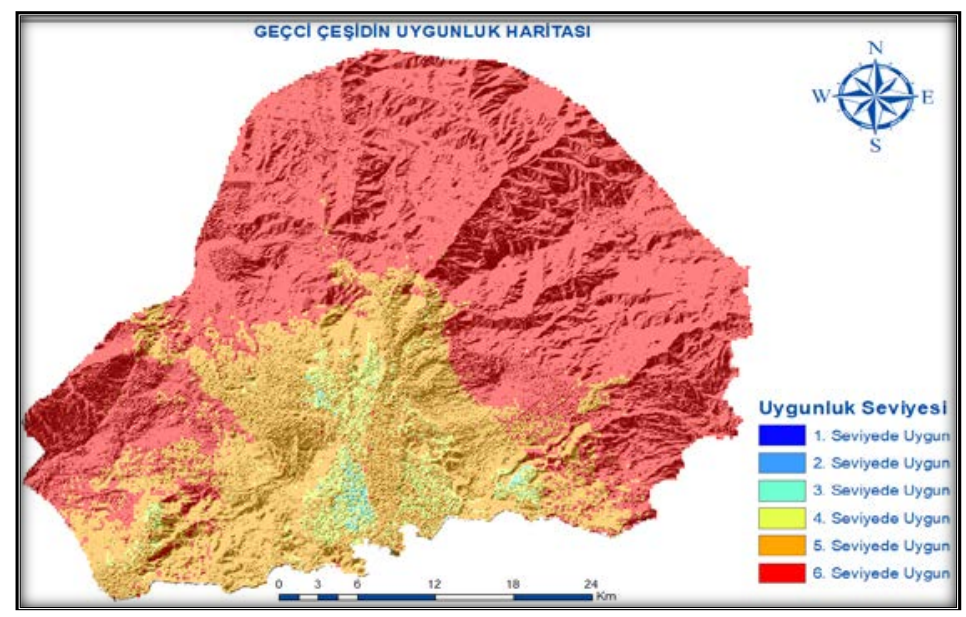

Şekil 7. Geçci çeşitlerin uygunluk seviyelere göre alan dağılımları.

2000 y1lı ve öncesinde bağcılık yapılan köyler

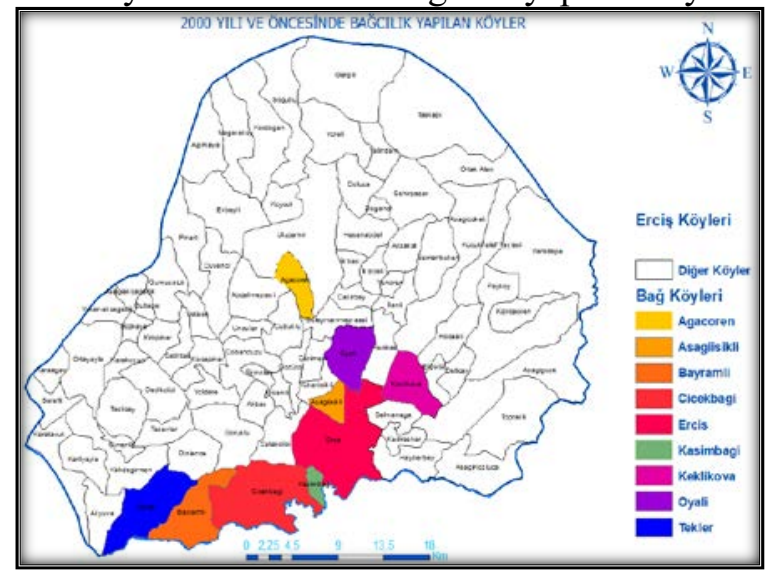

2019 yılı bağc1lı yapılan köyler

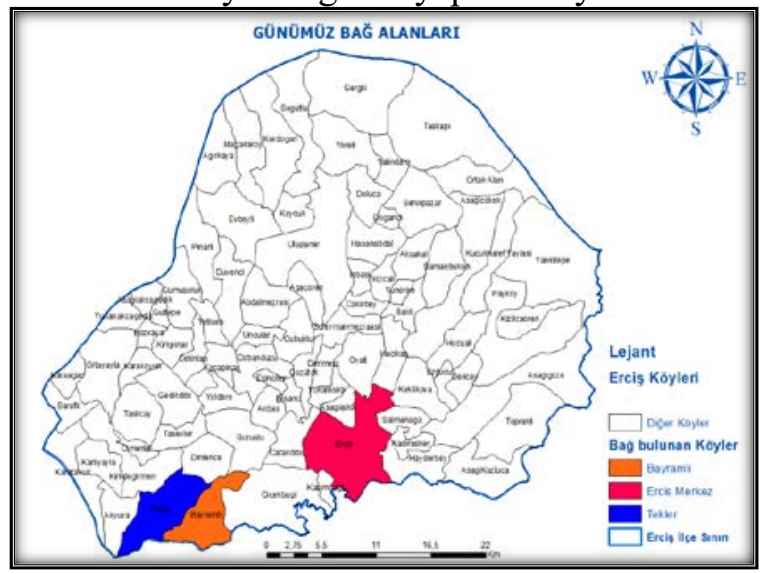

Şekil 8. 2000 yılı öncesi ve günümüzde bağ yetiştirilen köyler.

\subsection{Erciş (Van) ilçesi bağcılığının dünü ve bugünü}

İlçede Bağcılığın son durumu hakkında görsel tespit olması ve gerçekleştirdiğimiz bu çalışmanın basit bir doğrulaması adına yapılan araştırmalar neticesinde ilçede 2000 yılı öncesi ve günümüz üretimin gerçekleştirilebildiği bağ alanları aşağıda sunulmuştur. 2000 yılı öncesi yetiştiricilik yapılan alanların tespitinde (Karaaslanl1, 2017) yararlanılmakla birlikte Erciş İlçe Tarım ve Orman Müdürlüğü arşivlerinden elde edilen bilgiler çerçevesinde bağcılık yapilabilen alan aşağıda gösterilmiştir. Erciş ilçesi bağcılığının 15-20 sene içerisindeki bağ alan kayıpları somut net bir şekilde verilen haritalarda gözlenmektedir (Şekil 8).

Van Gölü’nün Ilımanlaştırıcı Etkisi bulunmaktadır. Şekil 9'da kıyıya $20 \mathrm{~km}$ mesafesinde bulunan Erciş ilçesi köylerini göstermektedir. Farklı olgunluk düzeylerinde elde edilen haritalardan da 
gözleneceği gibi gerek tespit edilen iyi derecede yetiştiricilik yapılabilecek alanlar itibariyle gerekse de eskiden günümüze bağ yetiştiriciliği yapılan alanlar açısından benzerlik gösterdiği gözlenmiştir. Buradan bağ yetiştiriciliği üzerine etki eden sekiz faktörün en önemli kısmını oluşturan iklim (etkili sıcaklık toplamı, donsuz gün sayısı vb.) etmeninin Van Gölünün etkisinde olduğu sonucuna ulaşılabilir. Gerçekten de iklim verileri karşılaştırıldığında Göl kıyısına yakın köylerin iklimsel değerlerinin daha mutedil olduğu görülmektedir.

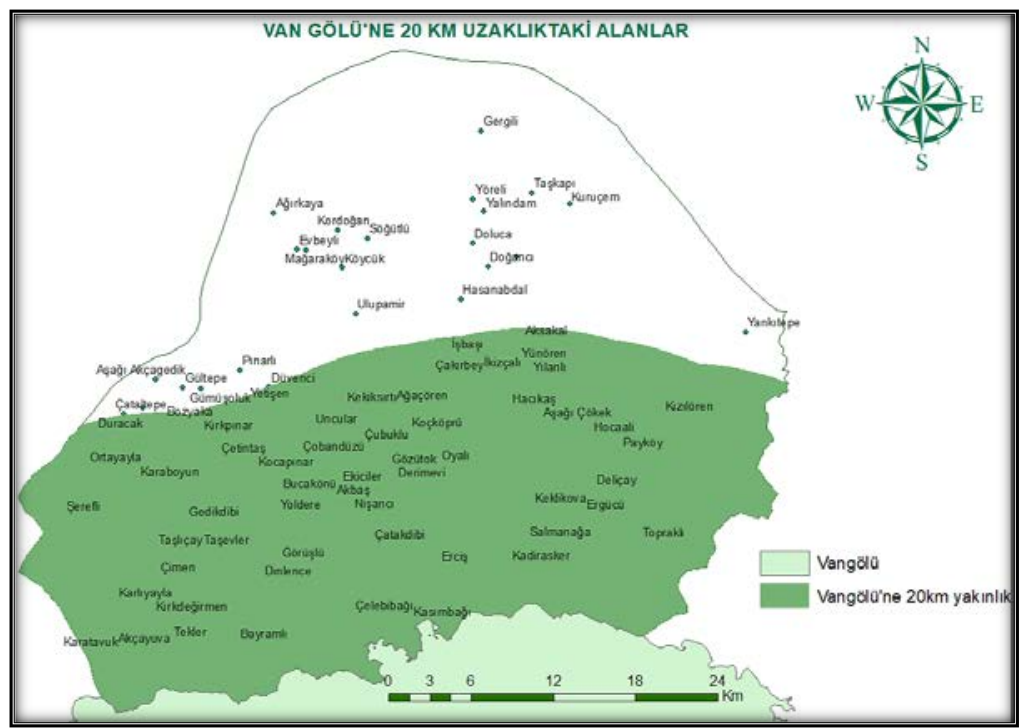

Şekil 9. Göl kenarından 20 km uzaklıktaki köyler.

\section{Sonuç ve Öneriler}

Bitkisel üretimde arazi kullanımı ve çevresel etkiler altında üretim kapasitesini artırmak önemlidir. Bunun için de bitki yetiştirilecek alanın toprak dağılımı, topografya ve iklim faktörleri bilinirse bitkinin bu istekleri doğrultusunda uygun alanlarda yetişmesi için hedeflenen alanlar belirlenmiş olur. Ürün yetiştirmede ekolojik faktörler göz önünde bulundurularak en uygun alanları belirlemek agroekolojik zonlamanın temelini oluşturmaktadır. Eğer bir bitki bölgeye iyi adapte olmuşsa ondan optimum şekilde faydalanmak için hangi çeşidin daha ekonomik açıdan öneminin olduğunu belirleyebilmek oldukça önemlidir. Çeşidin bölgeye uyumu ve optimum yarar sağlaması için bölgesel olarak yapılan çalışmalarla aynı çeşidin aynı ekolojide farklı bölgelerde vermiş olduğu ürün değerlendirmeleri göz önüne alınmalıdır. Erciş ilçesinin iklim istekleri belirlenmiş, ekonomik önemi olan ve optimum verimli olabilecek çeşitler üzerinden yapılan bu çalışmanın üreticiye sağlayacağı faydaları ve ona yönelmenin getireceği avantajları iyi kullanarak doğru yerde doğru ürünü en uygun zamanda yetiştirerek pazara sunulması ülkemiz tarımına ve üreticilerine önemli katkılar sağlayacaktır.

Tarımsal kayıt, bir bölgede veya belirlenmiş bir alanda üretim alanı ve tarımsal ürünlerin verimi üzerine bilgi toplama işidir. Tarımsal kayıt ile tarımsal üretimi ve mekânsal dağılımı ölçebilmek, kırsal yapıyı karakterize edebilmek, tarım politikalarının denetimi ve geliştirilmesini kolaylaştırabilmek, tarım kredilerinin dağılımını optimize edebilmek, ürün verimini tahmin edebilmek ve araştırma verileri üretebilmek mümkündür. Tarımsal bir kaydın başarısı ise coğrafi referanslama yoluyla, diğer mekânsal bilgilerin entegrasyonuna izin vermek için bölgelerin ve coğrafi konumların doğru ölçülmesi ile mümkündür. Bu çalışmada, Van ili Erciş ilçesi ve köylerinde hedeflenen araştırmaya konu üzüm çeşitlerinin yetiştirilebileceği uygun alanların belirlenen faktörler doğrultusunda CBS ile belirlenmiştir.

Yükseklik analizi sonucunda, mevcut bağ alanlarının denizden 1662-1755 m, Van Gölü seviyesinden 14-170 m yükseklikte konumlandığ gözlenmiştir. Bu yükseklik değerleri fazla görünse bile dünyanın en büyük sodalı gölü olan Van Gölü’nün yumuşatıcı etkisi bir mikroklima özelliği sunmakta ve bağcılık bu mikroklima alanlarda yapılabilmektedir.

Çalışma alanı 165427 ha'lık bir alanı kapsamaktadır. Bu alana ait eğim dağılımları; \% 0-2 eğime sahip düz araziler 11707 ha, \% 2-6 hafif eğimli araziler 47882 ha, \% 6-12 orta eğimli araziler 46526 ha, \% 12-20 dik eğimli araziler 31539 ha, \% 20-30 çok dik eğimli araziler 20562 ha, \% 30 ve 
üstü eğim gösteren sarp araziler ise 7210 ha alanı kaplamaktadır. Yörede yetiştiriciliği yapılan bağların hafif eğimli ve düz arazilerde bulunduğu gözlemlenmiştir.

Bakı analizi sonucunda mevcut bağ alanlarının genel olarak güneydoğu, güney, güneybatı, batı ve kuzeybatı yönlerine baktığı ve bu durumun ekonomik bir bağcılık açsından sıkıntı oluşturmadığ1 tespit edilirken, yeni kurulacak bağlarda yöney seçimine dikkat edilmesi ve bağların öncelikle güney yönü tercih edilmekle birlikte güneybatı, güneydoğu, batı ve doğu yönlerine kurulması önerilmektedir.

Yapılan çalışmada belirlenen sekiz kriter çerçevesinde, iklim, topografik ve toprak kriter analizleri sonucunda çok erkenci, erkenci (1.-3. uygunluk seviyelerinde) ve orta erkenci (1. ve 2. uygunluk seviyelerinde) çeşitlerin yetiştirilmesinde tespit etmiş bulunduğumuz alanlar kapsamında herhangi bir sorunun bulunmadığ 1 anlaşılmıştır. Orta mevsim çeşitlerinin yetiştirilmesinde kısıtlı (1. uygunluk seviyesinde) belirlenen alanlarda çok düşük düzeyde yetişmesi temin edilebileceği öngörülmektedir. Yörede geçci çeşitlerin yetiştirilmesinin mümkün olmadığı anlaşılmaktadır.

$\mathrm{Bu}$ çalışma, yörede üzüm çeşit seçimine yönelik modelleme doğrultusunda CBS ile uygunluk haritalarının belirlenmesi üzerine yapılan ilk çalışma olması bakımından önemlidir. CBS, bağ alanlarının belirlenmesinde zaman, maliyet ve doğruluk açısından büyük avantajlar sağlamıştır. Bu çalışmanın bundan sonraki bağ kurulabilecek alanların köy bazlı olarak tespit edilmiş olması yöreye katk1 sunmas1 umut etmekteyiz.

\section{Kaynakça}

Ahmedullah, M. \& Himelrick, D. G. (1990). Grape management. In Small Fruit Crop Management, 383-471. Englewood Clilffs, NJ: Prentice Hall.

Akbaş, F., Ünlükara, A., Kurunç, A., İpek, U., \& Yıldız, H. (2008). Tokat-Kazova'da taban suyu gözlemlerinin CBS yöntemleriyle yapılmast ve yorumlanması. Sulama ve Tuzlanma Konferansı. 12-13 Haziran 2008, Şanliurfa. 217-226.

Alsancak, B. (2005). Gediz havzasında iklim isteklerine göre farkl üzüm çeşitlerinin yetiştirilebileceği alanların belirlenmesi (yüksek lisans tezi, basılmamış). Ankara Üniversitesi, Fen Bilimleri Enstitüsü, Ankara.

Alsancak Sırlı, B., Peşkircioğlu, M., Torunlar, H., Özaydın, K. A., Mermer, A., Kader, S., Tuğaç, M.G., Aydoğmuş, O., Emeklier, Y., Yıldırım Y. E., \& Kodal, S. (2015). Türkiye’de üzüm (Vitis spp.) yetiştirmeye uygun potansiyel alanların Coğrafi Bilgi Sistemleri (CBS) teknikleri kullanılarak iklim ve topografya faktörlerine göre belirlenmesi. Tarla Bitkileri Merkez Araştırma Enstitüsü Dergisi, 24 (1), 56-64.

Anonim, (2000). Çeşit Kataloğu. Tarım Orman ve Köyişleri Bakanlığı, Atatürk Bahçe Kültürleri Merkez Araştırma Enstitüsü, Yalova.

Anonim, (2008). Toprak ve Arazi Sinıflaması Standartları Teknik Talimatı. T.C. Tarım ve Köyiş̧leri Bakanlığı Tarımsal Üretim ve Geliştirme Genel Müdürlüğü Yayınları, Say: 19-20.

Anonim, (2018). Climate Data. http://www.usclimatedata.com. Erişim tarihi: 15.05 .2018

Anonim, (2019). Türkiye İstatistik Kurumu 2018. www.tuik.gov.tr. Erisim tarihi: 22.02.2019

Boyer, J. (1998). Geographic analysis of viticulture potential in virginia. (PhD), Thesis Virginia Polytechnical Institute and State University.

Çelik, H., Ağaoğlu, Y. S., Fidan, Y., Marasalı, B., \& Söylemezoğlu, G. (1998). Genel Băgcılık. Sun Fidan A.Ş. Mesleki Kitaplar Serisi No:1, 253s.

Çelik, H. (2002). Üzüm Çeşit Kataloğu. Sun Fidan A.Ş. Mesleki Kitaplar Serisi No: 2, Ankara. 137s.

Çelik, H. (2018). Dünya sofralık üzüm üretimi ve ticareti. Türkiye 9. Bağc1lık ve Teknolojileri Sempozyumu, 15-16s.

Day, R. L. (2006). Pennsylvania state vineyard assessment system. penn state university site assessment. www.vineyardmap.psu.edu, Erişim tarihi: 19.01.2019.

Fiola, J. A. (2005). Site suitability evaluation for starting vineyards in maryland

Gazioğlu-Şensoy, R. İ., \& Balta, F. (2010). Bazı üzüm çeşitlerinin Van ekolojik şartlarına adaptasyonu. Yüzüncü Yıl Üniversitesi Tarım Bilimleri Dergisi, 20(3), 159-170. 
Gregory, V., Jones-Nicholas, S., \& Peder, N. (2004). Geology and wine 8, modeling viticultural landscapes: A GIS Analysis of the Terroir Potential in the Umpqua Valley of Oregon, Southern Oregon University.

Karaaslanlı T. (2017). Van ili Erciş ilçesindeki mevcut bă̆ alanlarının coğrafi bilgi sistemleri (CBS) ile belirlenmesi, (Yüksek lisans tezi, basılmamış). Van Yüzüncü Yı1 Üniversitesi Fen Bilimleri Enstitüsü, Van.

Kurtural K. S., Wilson P. E., \& Imed E. (2008). Vineyard site selection in Kentucky, based on climate and soil properties. University of Kentucky cooperative extension service. (UK, CES HO-87) 1-4p. USA.

Öztürk H. (1996). Sofralık Üzüm Çeşitleri ve Adaptasyonu. Yayın no:61. Bağcılık Araştırma Enstitüsü Müdürlüğ̈̈-Manisa.

Uyak, C., \& Gazioğlu-Şensoy, R. İ. (2009). Van ili bağc1lığının mevcut durumu, sorunları ve çözüm önerileri. Yüzüncü Yll Üniversitesi Tarım Bilimleri Dergisi, 19(2), 103-111.

Winkler, A. J., Cook, J. A., Kliewer, W. M., \& Lider, L. A. 1974. General Viticulture, California: U. of Calif. P., 710p.

Yıldırım, Y. E. (2002). GAP Bölgesinde Çeşitli Bitkilerin Yetişebileceği Alanların Belirlenmesi. T.C. Başbakanlık GAP Bölge Kalkınma İdaresi Başkanlığı Güney Doğu Anadolu Projesi Bölge Kalkınma Planı, GAP Bölgesinde Sulama Durumu, İklim, Bitki ve Türdeş Alanlar, 147-197s. 